\title{
HUBUNGAN KEEFEKTIFAN PEMBINAAN DAN PENGEMBANGAN KEPROFESIAN BERKELANJUTAN DENGAN KINERJA GURU DALAM PEMBELAJARAN SMKN DI KOTA MALANG
}

\author{
Mutya Alfarina \\ Djum Djum Noor Benty \\ Desi Eri Kusumaningrum
}

\author{
Universitas Negeri Malang, Jalan Semarang 5 Malang 65145 \\ Email: Mutyaalfarina08@gmail.com
}

\begin{abstract}
: the goal of this research was to know: (1) the level effectiveness of teachers' coaching events in all vocational high schools in Malang City; (2) the effective level of sustainable professionalism at vocational high schools Malang City; (3) the level teachers' teaching performance at vocational high schools Malang City; (4) the correlation between coaching and teachers' teaching performance at vocational high schools Malang City; (5) the correlation between development of sustainable professionalism and teachers' teaching performance at vocational high schools Malang City; and (6) the correlation between coaching and development of sustainable professionalism with teachers' teaching performance at vocational high schools. This research used quantitative approach with using correlational descriptive design. Based on analysis data, there were six conclusions as followed: (1) the level effectiveness of teachers' coaching in all vocational high schools in Malang City was in moderate category; (2) the level effectiveness development of sustainable professionalism (DSP) in all vocational high schools in Malang City was in low category; (3) the level of teachers' performance for learning in all vocational high schools in Malang City was high category; (4) there was no relationship significantly between effectiveness of coaching and using teachers' performance in all vocational high schools in Malang City; (5) there was low relationship between development of sustainable professionalism and teachers' performance for learning development of sustainable professionalism in all vocational high schools in Malang City; and (6) there was low relationship coaching and development of sustainable professionalism using teachers' performance for learning.
\end{abstract}

Keyword: Coaching; development of sustainable professionalism; teachers' teaching performance

Abstrak: Penelitian ini dilaksanakan dengan tujuan untuk mengetahui: (1) tingkat keefektifan kegiatan pembinaan guru SMKN di Kota Malang; (2) tingkat keefektifan kegiatan pengembangan profesi guru berkelanjutan SMKN di Kota Malang; (3) tingkat kinerja guru dalam pembelajaran SMKN di Kota Malang; (4) hubungan antara keefektifan pembinaan dan kinerja guru dalam pembelajaraan SMKN di Kota Malang; (5) hubungan antara pengembangan keprofesian berkelanjutan dan kinerja guru dalam pembelajaran SMKN di Kota Malang; dan (6) hubungan keefektifan pembinaan dan pengembangan keprofesian berkelanjutan dengan kinerja guru dalam pembelajaran SMKN di Kota Malang. Penelitian ini menggunakan pendekatan kuantitatif dengan rancangan penelitian bersifat deskriptif korelasional. Kesimpulan dari penelitian adalah: (1) tingkat keefektifan pembinaan guru SMKN di Kota Malang masuk dalam tingkatan kategori sedang; (2) tingkat keefektifan pengembangan keprofesian berkelanjutan (PKB) guru SMKN di Kota Malang masuk dalam tingkatan kategori rendah; (3) tingkat kinerja guru dalam pembelajaran SMKN di Kota Malang masuk dalam tingkatan kategori tinggi; (4) tidak ada hubungan yang signifikan antara keefektifan pembinaan dengan kinerja guru SMKN di Kota Malang; (5) ada hubungan rendah antara pengembangan keprofesian berkelanjutan (PKB) dengan kinerja guru dalam 
pembelajaran SMKN di Kota Malang; dan (6) ada hubungan sangat rendah keefektifan pembinaan dan pengembangan keprofesian berkelanjutan (PKB) dengan kinerja guru dalam pembelajaran.

Kata Kunci: pembinaan; pengembangan keprofesian berkelanjutan; kinerja guru dalam pembelajaran

Kualitas guru memberikan andil yang besar terhadap kualitas pendidikan. Oleh sebab itu, kemampuan dan keahlian yang dimiliki guru harus terus menerus dibina dan dikembangkan, dalam hal ini institusi pemerintah dan satuan pendidikan (sekolah) harus ikut andil. Guna memenuhi kewajiban dan menjalankan tugas-tugas profesional yang diwujudkan dalam bentuk kinerja, guru dituntut untuk melakukan suatu proses penumbuhan dan pengembangan profesinya. Kinerja yang optimal merupakan bukti nyata dari seorang guru yang profesional. Kinerja guru terlihat dan dapat diukur dari rasa tanggungjawab menjalankan amanah dan profesi yang diemban. Suharsaputra (2010:20) memaparkan bahwa kinerja guru merupakan perilaku atau sikap yang dihasilkan seorang guru dalam melaksanakan tugasnya sebagai pendidik dan pengajar saat mengajar di depan kelas yang sesuai dengan kriteria tertentu.

Perlu adanya usaha yang terus-menerus agar guru tetap memiliki pengetahuan dan keterampilan sesuai dengan tuntutan kurikulum yang berlaku. Upaya yang dapat dilakukan yakni melalui kegiatan pembinaan dan pengembangan keprofesian. Efektif atau tidaknya pembinaan yang dilakukan dapat dilihat dari adanya perubahan kinerja guru pasca dilakukan pembinaan. Selain itu juga dilakukan upaya pengembangan keprofesian berkelanjutan dimana pemetaan kompetensinya telah dilakukan melalui UKG (Uji Kompetensi Guru) sehingga dapat diketahui kondisi guru serta kebutuhan peningkatan kompetensinya. Sesuai yang dipaparkan dalam Petunjuk Teknis Pelaksanaan Pengembangan Keprofesian Berkelanjutan, tujuan utama dilaksanakan Pengembangan Keprofesian Berkelanjutan (PKB) ialah untuk meningkatkan kompetensi guru yang ditunjukkan dengan kenaikan capaian nilai UKG dengan rata-rata nasional yaitu 70 .

Penelitian ini dilakukan di Kota Malang. Kota Malang merupakan salah satu kota pendidikan vokasi di mana telah berkembang maju SMKN. Peneliti memilih SMKN karena di Malang SMKN banyak diminati, tentunya dengan adanya kualitas pendidikan yang diselenggarakan dan guru yang kompeten. Penelitian sejenis pernah dilakukan oleh Hadi (2015) memperoleh kesimpulan bahwa pelaksanaan pembinaan guru dalam mengimplementasikan pembelajaran di SMAN se-Kota Malang termasuk dalam kategori tinggi. Tingkat kemampuan guru dalam mengimplementasikan pembelajaran juga masuk dalam kategori tinggi. Terdapat hubungan yang signifikan antara pembinaan guru dan kemampuan guru mengimplementasikan pembelajaran di SMAN se-Kota Malang. Penelitian lain juga dilakukan oleh Rukmana (2016) memperoleh kesimpulan bahwa frekuensi keikutsertaan guru SMKN se-Kota Malang dalam program pengembangan masuk dalam tingkat sering sedangkan kualitas keikutsertaan masuk pada kategori sedang. Kualitas kinerja profesional guru termasuk dalam kategori cukup profesional. Terdapat hubungan yang signifikan antara keikutsertaan dalam program pengembangan dan kinerja profesional guru SMKN se-Kota Malang pada kategori rendah.

Pembaharuan dalam penelitian yang peneliti lakukan ini terletak pada variabel keefektifan pembinaan dan pengembangan keprofesian berkelanjutan yang dilakukan guru berstatus Pegawai Negeri Sipil (PNS) dalam lingkup SMKN di Kota Malang serta variabel kinerja guru dalam lingkup pembelajaran. Peneliti hanya mengambil populasi guru PNS dikarenakan pengembangan keprofesian berkelanjutan wajib dilakukan guru dengan golongan ruang IIIa sampai dengan IVe. Penelitian ini dilakukan untuk mengetahui keeefektifan kegiatan pembinaan guru dan pengembangan keprofesian berkelanjutan SMKN di Kota Malang, tingkat kinerja guru dalam pembelajaran SMKN di Kota Malang, hubungan keefektifan pembinaan dan kinerja guru dalam pembelajaraan SMKN di Kota Malang, hubungan pengembangan keprofesian berkelanjutan dan kinerja guru dalam pembelajaran SMKN di Kota Malang, dan hubungan keefektifan pembinaan dan pengembangan profesi berkelanjutan dengan kinerja guru dalam pembelajaran SMKN di Kota Malang. Hipotesis dalam penelitian ini (a) Ada hubungan antara keefektifan pembinaan dengan kinerja guru dalam pembelajaran SMKN di Kota 
Malang; (b) Ada hubungan antara pengembangan keprofesian berkelanjutan (PKB) dengan kinerja guru dalam pembelajaran SMKN di Kota Malang; (c) Ada hubungan antara keefektifan pembinaan dan pengembangan keprofesian berkelanjutan (PKB) dengan kinerja guru dalam pembelajaran SMKN di Kota Malang. Penelitian ini dapat digunakan sebagai alternatif peningkatan mutu pendidik (guru) dalam mengembangkan kompetensi dan kinerjanya dalam pembelajaran, terutama untuk guru SMKN di Kota Malang.

\section{METODE}

Penelitian ini termasuk dalam penelitian kuantitatif dengan model analisis deskriptif korelasi. Penelitian deskriptif korelatif yaitu suatu metode penelitian yang bertujuan untuk melihat hubungan antara dua variabel atau lebih. Variabel bebas dalam penelitian ini, yaitu keefektifan pembinaan dan pengembangan keprofesian berkelanjutan. Variabel terikatnya yakni kinerja guru dalam pembelajaran.

Populasi dalam penelitian ini yakni 13 SMKN di Kota Malang. Teknik pengambilan sampel menggunakan Area Proportional Random Sample. Dari hasil perhitungan diperoleh 5 sampel dengan jumlah guru PNS sebanyak 118 orang. Sampel dari penelitian hanya guru PNS dikarenakan kegiatan pengembangan keprofesian berkelanjutan wajib dilakukan oleh guru dengan golonan IIIa sampai dengan golongan ruang IVe. Instrumen yang digunakan dalam penelitian ini yakni kuesioner (angket). Bentuk angket yang digunakan dalam penelitian ini yaitu angket tertutup dengan cara responden memberi jawaban yang sesuai dengan kondisi responden. Pengukuran angket menggunakan Skala Likert.

Teknik analisis data yang digunakan dalam penelitian ini menggunakan analisis deskriptif dan analisis korelasi. Teknik deskriptif digunakan untuk mendeskripsikan suatu kondisi variabel-variabel dalam penelitian. Teknik deskriptif ini digunakan untuk mendeskripsikan skor data pembinaan guru, skor data pengembangan profesi berkelanjutan, dan skor data kinerja guru dalam pembelajaran SMKN di Kota Malang. Uji hipotesis dalam penelitian ini menggunakan teknik analisis korelasi Product Moment Pearson dan korelasi berganda. Analisis korelasi Product Moment Pearson digunakan untuk mengetahui hubungan antara variabel satu dengan variabel lainnya. Analisis korelasi berganda digunakan untuk mengetahui hubungan antara dua atau lebih variabel bebas secara bersama-sama dengan suatu variabel terikat. Pengambilan kesimpulan adalah $\mathrm{H}_{0}$ ditolak jika nilai signifikasi $<0,05$ dengan maksud terdapat hubungan antara variabel yang diolah, sebaliknya $\mathrm{H}_{0}$ diterima jika nilai signifikasi $>0,05$ dengan maksud tidak terdapat hubungan antara variabel yang diolah.

\section{HASIL}

\section{Tingkat Keefektifan Pembinaan SMKN di Kota Malang}

Berdasarkan penelitian menunjukkan bahwa dari 118 responden sebanyak 18 orang atau $15,2 \%$ memiliki tingkat keefektifan pembinaan yang tinggi, sebanyak 88 orang atau $74,6 \%$ memiliki tingkat keefektifan pembinaan sedang, dan 12 orang atau 10,2\% memiliki tingkat keefektifan pembinaan yang rendah. Berikut diagram tingkat keefektifan pembinaan guru pada Gambar 1

Tingkat Keefektifan Pembinaan Guru SMKN di Kota Malang

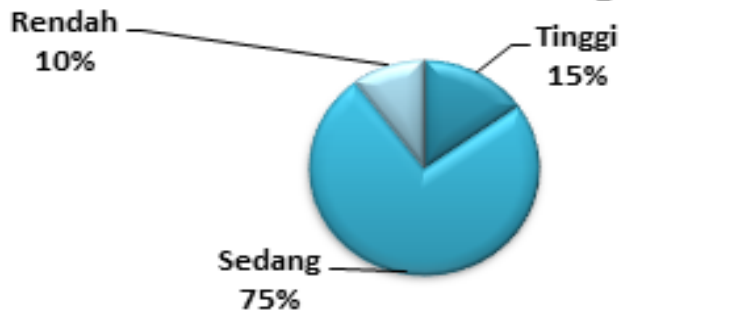

Gambar 1 Tingkat Keefektifan Pembinaan Guru 


\section{Tingkat Keefektifan Pengembangan Keprofesian Berkelanjutan (PKB) SMKN di Kota Malang}

Berdasarkan hasil penelitian menunjukkan bahwa dari 118 responden sebanyak 4 oang atau 3,4\% yang melaksanakan pengembangan keprofesian berkelanjutan (PKB) masuk dalam kategori tinggi, sebanyak 50 orang atau $42,3 \%$ yang melaksanakan pengembangan keprofesian berkelanjutan (PKB) masuk dalam kategori sedang, dan 64 orang atau 54,3\% yang melaksanakan pengembangan keprofesian berkelanjutan (PKB) masuk dalam kategori rendah. Berikut diagram tingkat keefektifan PKB pada Gambar 2

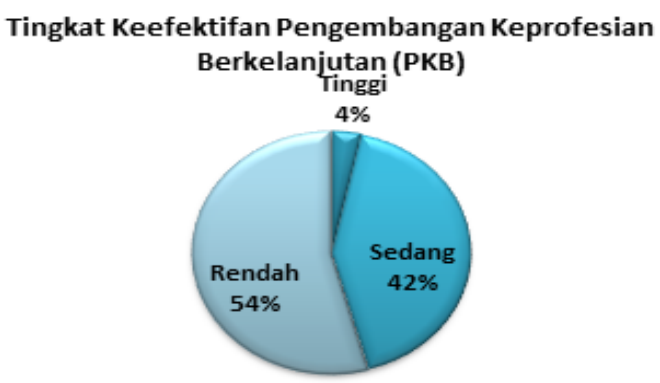

Gambar 2 Tingkat Keefektifan Pengembangan Keprofesian Berkelanjutan (PKB)

\section{Tingkat Kinerja Guru dalam Pembelajaran}

Berdasarkan hasil penelitian menunjukkan bahwa dari 118 responden sebanyak 58 orang atau $49,0 \%$ memiliki tingkat kinerja yang tinggi, sebanyak 53 orang atau 45,0\% memiliki tingkat kinerja sedang, dan 7 orang atau $6,0 \%$ memiliki tingkat kinerja yang rendah. Berikut diagram tingkat kinerja guru dalam pembelajaran guru pada Gambar 3

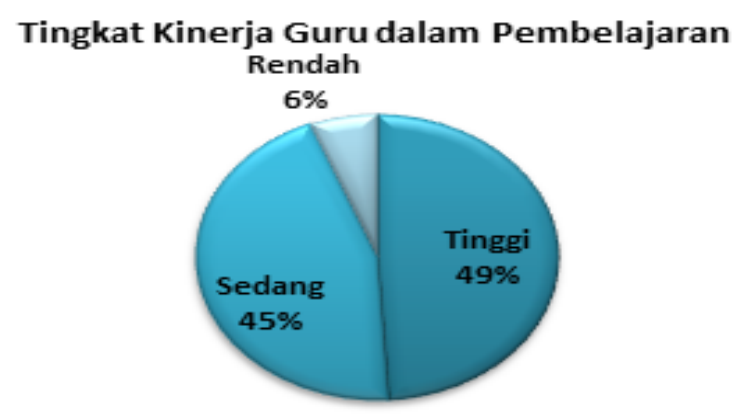

Gambar 3 Tingkat Kinerja Guru dalam Pembelajaran

\section{Uji Hipotesis}

Pengujian hipotesis berdasarkan analisis yang telah dihitung dan dideskripsikan, yaitu analisis data variabel keefektifan pembinaan $\left(\mathrm{X}_{1}\right)$ dengan variabel pengembangan keprofesian berkelanjutan $\left(\mathrm{X}_{2}\right)$ dengan kinerja guru dalam pembelajaran (Y). Uji hipotesis ini menggunakan rumus korelasi Product Moment Pearson, dengan begitu akan diketahui ada atau tidaknya hubungan antara variabel bebas dan variabel terikat. 
Tabel 1 Analisis Korelasi Product Moment Pearson

\begin{tabular}{lllll}
\hline & & $\begin{array}{l}\text { Keefektifan } \\
\text { Pembinaan }\end{array}$ & $\begin{array}{l}\text { Pengembangan Kepro- Kinerja Guru dalam } \\
\text { fesian } \\
\text { (PKB) }\end{array}$ & Berkelanjutan \\
\hline Pembinaan & Pearson Correlation & 1 & 0,064 & $-0,039$ \\
& Sig. (2-tailed) & & 0,493 & 0,675 \\
& $\mathrm{~N}$ & 118 & 118 & 118 \\
PKB & Pearson Correlation & 0,064 & 1 & 0,283 \\
& Sig. (2-tailed) & 0,493 & & 0,009 \\
\multirow{5}{*}{ Kinerja Guru } & Nearson Correlation & $-0,039$ & 0,238 & 118 \\
& Sig. (2-tailed) & 0,675 & 0,009 & 1 \\
& $\mathrm{~N}$ & 118 & 118 & 118 \\
\hline
\end{tabular}

Kriteria pengambilan kesimpulan adalah $\mathrm{H}_{0}$ ditolak jika nilai signifikasi $<0,05$ dengan maksud terdapat hubungan antara variabel yang diolah, sebaliknya $\mathrm{H}_{0}$ diterima jika nilai signifikasi $>0,05$ dengan maksud tidak terdapat hubungan antara variabel yang diolah. Pada Tabel 1 menunjukkan nilai signifikasi $0,675>0,05$ maka $\mathrm{H}_{0} \mathrm{~d}$ iterima. Maka hipotesis pertama terjawab, yakni tidak ada hubungan yang signifikan antara keefektifan pembinaan dan kinerja guru dalam pembelajaran. Tabel 1 menunjukkan nilai signifikasi $0,009<0,05$ maka $\mathrm{H}_{0}$ ditolak. Maka hipotesis kedua terjawab, ada hubungan rendah antara pengembangan keprofesian berkelanjutan (PKB) dengan kinerja guru dalam pembelajaran di SMKN Kota Malang. Korelasi diantara kedua variabel dinyatakan berhubungan dengan koefisien korelasi "rendah" sebesar 0,238. Interpretasi koefisien korelasi dapat dilihat pada Tabel 2 berikut.

Tabel 2 Interpretasi Koefisien Korelasi

\begin{tabular}{ll}
\hline Nilai Koefisien & Tingkat Hubungan \\
\hline $0,800-1,000$ & Sangat kuat \\
$0,600-0,799$ & Kuat \\
$0,400-0,599$ & Cukup kuat \\
$0,200-0,399$ & Rendah \\
$0,000-0,199$ & Sangat rendah \\
\hline
\end{tabular}

Sumber : Sugiyono (2013:257)

Uji hipotesis ketiga menggunakan teknik analisis korelasi berganda. Pada Tabel 1 telah diketahui bahwa tidak ada hubungan yang signifikan antara variabel keefektifan pembinaan $\left(\mathrm{X}_{1}\right)$ dengan pengembangan keprofesian berkelanjutan $\left(\mathrm{X}_{2}\right)$. Tidak ada hubungan yang signifikan antara variabel keefektifan pembinaan dan kinerja guru dalam pembelajaran (Y). Ada hubungan yang signifikan antara pengembangan keprofesian berkelanjutan $\left(\mathrm{X}_{2}\right)$ dengan kinerja guru dalam pembelajaran $(\mathrm{Y})$. Masingmasing koefisien korelasi variabel-variabel tersebut adalah 0,064 korelasi antara keefektifan pembinaan dengan pengembangan keprofesian berkelanjutan, $-0,039$ korelasi antara variabel keefektifan pembinaan dengan kinerja guru dalam pembelajaran dan 0,283 korelasi antara variabel pengembangan keprofesian berkelanjutan dengan kinerja guru dalam pembelajaran. Ketiga nilai koefisien korelasi tersebut dimasukkan dalam rumus korelasional berganda untuk mengetahui hubungan secara simultan antara variabel $\mathrm{X}_{1}$ dan $\mathrm{X}_{2}$ terhadap variabel $\mathrm{Y}$. Berdasarkan perhitungan diketahui terdapat korelasi positif antara keefektifan pembinaan dan pengembangan keprofesian berkelanjutan (PKB) dengan kinerja guru dalam pembelajaran secara simultan dengan nilai koefisien korelasi sebesar 0,029. Hubungan ini jika dilihat pada Tabel 2 Interpretasi Koefisien Korelasi maka menunjukkan sangat rendah. 


\section{PEMBAHASAN}

\section{Tingkat Keefektifan Pembinaan Guru SMKN di Kota Malang}

Hasil penelitian menunjukkan bahwa keefektifan pembinaan guru masuk dalam kategori sedang. Setiap guru memiliki kesan yang berbeda terhadap keefektifan pembinaan yang telah berjalan. Efektif atau keefektifan adalah berhasil guna, dimana untuk mengukur seberapa tujuan yang telah ditetapkan dapat tercapai. Pembinaan guru dilakukan untuk memberikan bantuan dalam mengembangkan situasi belajar mengajar yang optimal dan lebih baik. Dalam hal ini, pembinaan guru dilakukan untuk mendukung penyelenggaraan situasi belajar dan pembelajaran yang lebih baik dan lebih efektif. Indikator pembinaan dapat dikatakan efektif adalah tercapainya sasaran atau tujuan pembinaan yang telah ditetapkan sebelumnya dimana juga dilakukan pengukuran mengenai seberapa jauh target telah tercapai.

Beberapa kegiatan dapat dilakukan untuk membina guru namun harus didukung oleh berbagai pihak. Sobri (2013) berpendapat bahwa pelaksanaan pembinaan dan pelatihan dilakukan bekerjasama dengan para pakar baik dari dinas pendidikan setempat maupun dengan perguruan tinggi. Selain itu sekolah juga mengadakan kerjasama dengan berbagai lembaga guna memberikan kontribusi yang besar dalam mengembangkan dan meningkatkan program sekolah. Terdapat 2 jenis pembinaan yang dapat dilakukan sesuai kebutuhan yakni pembinaan kemampuan dan pembinaan komitmen.

Pembinaan guru SMKN di Kota Malang dalam kategori sedang dikarenakan guru hanya melaksanakan satu dari tiga bentuk pembinaan kemampuan tersebut. Misalnya guru hanya melaksanakan pembinaan kemampuan dengan supervisi akan tetapi tidak pernah atau jarang mengikuti kegiatan pelatihan. Sebaliknya, guru jarang mendapat supervisi dari kepala sekolah atau pengawas tetapi guru aktif dalam mengikuti kegiatan pelatihan. Selain supervisi dan pelatihan, bentuk pembinaan kemampuan juga berupa pendidikan lanjutan. Namun mayoritas guru tidak menempuh pendidikan lanjutan ketika sudah dalam masa jabatan mengajar. Pembinaan komitmen dilakukan berupa pemberian pembinaan kesejahteraan bagi guru. Hal tersebut sesuai dengan pendapat Bafadal (2003:44) yang menyatakan bahwa pembinaan komitmen dapat berupa pembinaan kesejahteraan misalnya guru melaksanakan sertifikasi dan mendapat tunjangan setelahnya. Mayoritas guru sudah melakukan sertifikasi dan mendapat tunjangan sertifikasi sesuai kebijakan yang berlaku.

\section{Tingkat Keefektifan Pengembangan Keprofesian Berkelanjutan Guru SMKN di Kota Malang}

Guru Pertama dengan pangkat Penata Muda golongan ruang IIIa sampai dengan pangkat pembina Utama golongan ruang IVe wajib melaksanakan kegiatan pengembangan keprofesian. Berdasarkan hasil penelitian yang menyatakan bahwa pengembangan keprofesian berkelanjutan masuk dalam kategori rendah dikarenakan guru belum melakukan kegiatan yang ada dalam unsur PKB tersebut. Menurut Peraturan Menteri Pendayagunaan Aparatur Negara dan Reformasi Birokrasi Nomor 16 Tahun 2009 tentang Jabatan Fungsional Guru dan Angka Kreditnya Bab V Pasal 11 Poin C, unsur kegiatan pengembangan keprofesian berkelanjutan meliputi kegiatan pengembangan diri, publikasi ilmiah, dan karya inovatif.

\section{Kinerja Guru dalam Pembelajaran}

Berdasarkan penelitian diperoleh hasil kinerja guru dalam pembelajaran masuk dalam tingkat kategori tinggi. Artinya, sebagian besar guru telah melaksanakan beberapa indikator kinerja guru dalam pembelajaran. Hal tersebut sesuai yang terkandung Dalam Panduan Kerja Pengawas Sekolah Pendidikan Dasar dan Menengah Tahun 2017 yang telah menetapkan indikator pengukuran kinerja guru dalam pelaksanaan pembelajaran yang dijabarkan dalam bentuk instrumen pengimplementasian Kurikulum 2013 yakni perencanan pembelajaran (RPP), pelaksanaan pembelajaran, dan penilaian atau evaluasi pembelajaran. Kinerja guru dalam pembelajaran dapat dilihat melalui Penilaian Kinerja Guru (PKG). Penilaian kinerja guru adalah penilaian dari tiap butir kegiatan tugas utama guru dalam rangka pembinaan karier kepangkatan dan jabatannya (Menteri Pendidikan Nasional Nomor 35 Tahun 2010 tentang Petunjuk Teknis Pelaksanaan Jabatan Fungsional Guru dan Angka Kreditnya). 


\section{Hubungan Keefektifan Pembinaan dengan Kinerja Guru dalam Pembelajaran di SMKN Kota Malang}

Berdasarkan hasil pengujian hipotesis pertama menyatakan bahwa tidak ada hubungan yang signifikan antara variabel keefektifan pembinaan $\left(\mathrm{X}_{1}\right)$ dengan kinerja guru dalam pembelajaran $(\mathrm{Y})$. Hal tersebut ditunjukkan dari hasil pengujian korelasi yang dilakukan dengan menggunakan SPSS for windows versi 16.0, didapatkan nilai signifikasi 0,675>0,05.

Pembinaan dapat dilakukan sesuai dengan kebutuhan guru. Hal ini sesuai dengan pernyataan Bafadal (2003:44) bahwa salah satu pembinaan guru ialah pembinaan komitmen yakni berupa pembinaan kesejahteraan, misalnya guru melaksanakan sertifikasi dan mendapat tunjangan setelahnya. Sertifikasi guru yang dilakukan oleh pemerintah, tujuan utamanya untuk meningkatkan kualitas guru, baik secara motivasi ataupun kinerja. Juwaeni (2014) menyatakan bahwa pada kenyataannya sertifikasi belum sepenuhnya berpengaruh secara signifikan, pembinaan guru selama ini belum secara komprehensif memperhatikan faktor-faktor yang berpengaruh terhadap kinerja.

Simpulan dari pernyataan di atas adalah pembinaan guru belum dilakukan secara efektif. Pembinaan komitmen guru berupa pemberian pembinaan kesejahteraan seperti sertifikasi belum berpengaruh secara signifikan terhadap kinerja guru termasuk dalam pembelajaran.

\section{Hubungan Pengembangan Keprofesian Berkelanjutan dengan Kinerja Guru dalam Pembelajaran di SMKN Kota Malang}

Berdasarkan hasil pengujian hipotesis kedua menyatakan bahwa ada hubungan yang signifikan antara variabel pengembangan keprofesian berkelanjutan $\left(\mathrm{X}_{2}\right)$ dengan kinerja guru dalam pembelajaran (Y). Hal tersebut ditunjukkan dari hasil pengujian korelasi dengan menggunakan SPSS for windows versi 16.0, didapatkan nilaai signifikasi $0,009<0,05$ dengan hasil korelasi 0,238 yang menunjukkan hubungan koefisien korelasi "rendah". Dari hasil korelasi tersebut dapat dinyatakan variabel pengembangan keprofesian berkelanjutan memiliki hubungan yang rendah terhadap kinerja guru dalam pembelajaran. Hasil penelitian ini sesuai penelitian yang sebelumnya telah dilakukan oleh Rukmana (2016) menyatakan bahwa terdapat hubungan yang signifikan antara keikutsertaan dalam program pengembangan dan kinerja profesional guru SMKN di Kota Malang.

Pengembangan keprofesian berkelanjutan dilaksanakan untuk menunjang kemampuan guru sebagai profesi. Hal tersebut sejalan dengan pernyataan Irwan (2016) bahwa pengembangan keprofesian berkelanjutan mendorong guru untuk memelihara dan meningkatkan standar mereka secara keseluruhan mencakup bidang-bidang berkaitan dengan pekerjaannya sebagai profesi. Tugas guru sebagai pendidik dan pengajar tentu saja tidak lepas dari seluruh unsur kegiatan pembelajaran di sekolah. Berkembangnya ilmu pengetahuan dan teknologi tentunya juga berpengaruh pada dunia pendidikan, dalam hal ini guru yang merupakan sumberdaya dalam pendidikan dituntut untuk meningkatkan standar mereka sebagai pendidik dan pengajar yang profesional.

Simpulan dari pernyataan di atas adalah pada dasarnya terdapat hubungan antara pengembangan keprofesian berkelanjutan dengan kinerja guru dalam pembelajaran. Unsur-unsur dalam pengembangan keprofesian berkelanjutan terdiri dari kegiatan pengembangan diri, publikasi ilmiah, dan karya inovatif yang harus diikuti oleh guru secara berkesinambungan sesuai dengan kebutuhan. Manfaat bagi guru yang melaksanakan pengembangan keprofesian berkelanjutan yakni mereka akan dapat memenuhi standar dan mengembangkan kompetensinya sehingga mampu melaksanakan tugas-tugas umumnya secara efektif sesuai dengan kebutuhan belajar dan pembelajaran peserta didik untuk menghadapi kehidupan di masa datang.

\section{Hubungan Keefektifan Pembinaan dan Pengembangan Keprofesian Berkelanjutan (PKB) dengan Kinerja Guru dalam Pembelajaran di SMKN Kota Malang}

Berdasarkan hasil pengujian hipotesis menyatakan bahwa ada hubungan yang signifikan antara variabel keefektifan pembinaan $\left(\mathrm{X}_{1}\right)$ dan pengembangan keprofesian berkelanjutan $\left(\mathrm{X}_{2}\right)$ dengan kinerja guru dalam pembelajaran (Y). Hal tersebut ditunjukkan dari hasil pengujian korelasi berganda dengan 
menggunakan SPSS for windows versi 16.0, didapatkan nilai korelasi 0,029 $<0,05$ menunjukkan hubungan koefisien korelasi "sangat rendah".

Guru dibina agar dapat mengembangkan keahlian dan kompetensinya yang diwujudkan dalam pembelajaran. Kinerja guru dalam pembelajaran merupakan salah satu tolok ukur keberhasilan seorang guru. Menurut Suharsaputra (2010: 20) kinerja guru adalah perilaku yang dihasilkan seorang guru dalam melaksanakan tugasnya sebagai pendidik dan pengajar ketika mengajar di depan kelas, sesuai dengan kriteria tertentu. Kriteria tersebut merupakan aspek yang harus ada sesuai yang diatur dalam Panduan Kerja Pengawas Sekolah Pendidikan Dasar dan Menengah Tahun 2017 terkait pembelajaran.

Hasil penelitian menyatakan bahwa variabel pembinaan dan pengembangan keprofesian berkelanjutan ada hubungan sangat rendah dengan kinerja guru dalam pembelajaran. Guru telah mengikuti kegiatan pembinaan dan pengembangan keprofesian berkelanjutan sesuai kebutuhannya untuk menunjang kemampuan dan profesionalitasnya. Wujud kinerja profesional guru daat dilihat dari kinerjanya yang optimal termauk dalam pembelajaran di sekolah.

\section{SIMPULAN DAN SARAN}

\section{Simpulan}

Tingkat keefektifan pembinaan guru SMKN di Kota Malang masuk dalam tingkatan kategori "sedang", artinya tidak semua guru mengikuti semua jenis pembinaan yang ada dalam metode pembinaan. Guru hanya melakukan jenis atau metode pembinaan sesuai kebutuhan. Tingkat keefektifan pengembangan keprofesian berkelanjutan (PKB) guru SMKN di Kota Malang masuk dalam tingkatan kategori"rendah". Dalam hal ini, sebagian besar guru PNS tidak atau belum melakukan unsur kegiatan pengembangan keprofesian berkelanjutan yang meliputi pengembangan diri, publikasi ilmiah, dan karya inovatif.

Tingkat kinerja guru dalam pembelajaran SMKN di Kota Malang masuk dalam tingkatan "kategori tinggi". Berarti sebagian besar guru telah melakukan pembelajaran dengan baik, yakni mencakup perencanaan pembelajaran, pelaksanaan pembelajaran, dan penilaian/evaluasi pembelajaran. Dalam kegiatan pelaksanaan pembelajaran juga harus memuat pendahuluan, isi, dan penutup. Pengukuran kinerja guru dilakukan melalui Penilaian Kinerja Guru (PKG). Tidak ada hubungan yang signifikan antara keefektifan pembinaan dengan kinerja guru dalam pembelajaran di SMKN Kota Malang. Dapat dikatakan bahwa pembinaan guru selama ini belum secara komprehensif memperhatikan faktor-faktor yang berkaitan dengan kinerja termasuk dalam pembelajaran.

Ada hubungan dengan kategori rendah antara pengembangan keprofesian berkelanjutan (PKB) dengan kinerja guru dalam pembelajaran di SMKN Kota Malang. Berarti bahwa pengembangan keprofesian berkelanjutan berkaitan dan berhubungan kinerja guru dalam pembelajaran. Akan tetapi, guru hanya mengikuti kegiatan yang terkandung dalam unsur pengembangan keprofesian berkelanjutan sesuai kebutuhan saja. Ada hubungan dengan kategori sangat rendah keefektifan pembinaan dan pengembangan keprofesian berkelanjutan (PKB) dengan kinerja guru dalam pembelajaran. Hal ini berarti menunjukkan bahwa pembinaan dan pengembangan keprofesian berkelanjutan ada keterkaitan dengan kinerja guru dalam pembelajaran. Kegiatan pembinaan dan pengembangan keprofesian berkelanjutan dilakukan oleh guru.

\section{Saran}

Bagi peneliti lain, sebagai bahan rujukan dalam sebuah penelitian namun dalam penelitian yang ditinjau dari sudut pandang yang berbeda. Seperti halnya suatu kegiatan pembinaan yang efektif apakah akan mempengaruhi tingkat kinerja guru yang tinggi. 


\section{DAFTAR RUJUKAN}

Bafadal, I. (2003). Peningkatan Profesionalisme Guru Sekolah Dasar, dalam Kerangka Manajemen Peningkatan Mutu Berbasis Sekolah. Jakarta: Bumi Aksara.

Hadi, D. (2015). Hubungan Pembinaan Guru dan Kemampuan Guru Mengimpelmentasikan Pembelajaran Sesuai Kurikulum 2013 di SMAN se-Kota Malang. (Skripsi tidak diterbitkan) FIP UM, Malang, Indonesia.

Irwan, C. (2016). Latar Belakang Pendidikan, Pengembangan Keprofesian Berkelanjutan, dan Produktivitas Guru SMA Negeri. Jurnal Manajemen Pendidikan Universitas Negeri Malang. 25 (2), 143-150.

Juwaeni, H. (2014). Kontribusi Kepemimpinan dan Komunikasi Kepala Sekolah terhadap Motivasi Kerja Guru dan Dampaknya terhadap Kinerja Guru SD di UPTD Dikpora Kota Surakarta. (Online), (http://eprints.ums. ac.id), diakses pada 6 Juli 2019.

Kementerian Pendidikan dan Kebudayaan. (2017). Panduan Kerja Pengawas Sekolah Pendidikan Dasar dan Menengah Tahun 2017. (Online), (repositori.kemdikbud.go.id), diakses pada 20 Maret 2019

Peraturan Menteri Pendidikan Nasional Nomor 35 Tahun 2010 tentang Petunjuk Teknis Pelaksanaan Jabatan Fungsional Guru dan Angka Kreditnya. Kementerian Pendidikan dan Kebudayaan. (Online), (kemdikbud. go.id), diakses pada 19 Maret 2019.

Kementerian Pendidikan Nasional Direktorat Pembinaan Pendidikan dan Tenaga Kependidikan. (2011). Peraturan Menteri Negara Pendayagunaan Aparatur Negara dan Reformasi Birokrasi Nomor 16 Tahun 2009 Tentang Jabatan Fungsional Guru dan Angka Kreditnya. Prosiding Seminar Nasional Pendidikan Ekonomi dan Bisnis. (Online), (http://jabatanfungsional.com), diakses pada 18 Maret 2019.

Rukmana, D. (2016). Hubungan antara Keikutsertaan dalam Program Pengembangan dan Kinerja Profesional Guru SMK Negeri se-Kota Malang. (Skripsi tidak diterbitkan) FIP UM, Malang, Indonesia.

Sobri, A. Y. (2013). Pembinaan Profesionalisme Guru dalam Meningkatkan Kualitas Pembelajaran. Jurnal Manajemen Pendidikan Universitas Negeri Malang. 24 (1), 9-20

Sugiono. (2013). Metodologi Penelitian Kuantitatif Kualitatif. Bandung: Alfabeta.

Sugiri, B. (2017). Kegiatan Pengembangan Keprofesian Berkelanjutan (PKB). (Online), (www.academia.edu), diakses pada 12 Juni 2019

Suharsaputra, U. (2010). Administrasi Pendidikan. Jakarta: Refika Aditama 